\title{
Governance Improving of the Corporate Sector and Private Corporate Structures at Various Levels of Management
} Irina Olegovna Bogdanova Anastasia Valerievna Kovaleva Lyubov Vasilievna Irinarkhova Azov State Technical University - branch of the Don State Technical University Email: kovaleva-drel@mail.ru

\author{
Doi:10.5901/mjss.2015.v6n3s6p347
}

\begin{abstract}
The purpose of writing this article was to consider financial planning as an indicator of the feasibility of a system of strategic planning of activity of enterprise, as well as a detailed description of the concept of "methodological gap", occurring between the strategic objectives of the Corporation's operations and tactic plans ABU. The solution to this problem by applying a method of indicative planning is identified. The concept of indicative planning is described in details, examples of its implementation in the corporate structures are given. The concept of early and late indicators and methods of their differentiation are given. As far as in the framework of corporate structure the issues of efficiency and a smooth internal business processes become important, it is necessary to develop and apply indicators in different areas: financial, personnel, client, etc. And since the integrated corporation is a large company, interacting with many counterparties, so in addition to the above key areas it is recommended to allocate the followings: communicative, innovative, implementation of a system of assessment tools, organizational, advertising direction, the direction of suppliers and contractors, the allocation of loans, the direction of investors, the direction of insurance companies In the article it is also noted that, despite successful examples of adaptation of various methods of financial planning for the needs of corporate structures, the problem of separation of the strategic plans of the corporation from their tactical plans of autonomous units remains relevant. An approach to its solution based on the method of indicative planning is proposed. The basic directions of development of indicators were observed.
\end{abstract}

Keywords: indicative planning, corporate sector, private corporate structures.

\section{Introduction}

Within corporate structures management and planning, in particular, become especially relevant. Thus, financial planning allows to determine the feasibility of the entire system of strategic planning in the framework of integrated corporate structures. Financial indicators serve as the indicators of the linkage between the strategic plan of the corporation and tactics plan $A B U$, included in its composition.

Currently financial planning finds wide application in practical financial and economic activities of corporations. Thus, there are the independent development and implementation of planning systems and also the involvement of consultants and the application of experience of major foreign companies and TCs. Despite the positive experience of implementation of various previously approved planning systems into the practice the economic problem of inconsistentcy of strategic plans of corporations and tactical plans $A B U$ remains relevant.

The reason for the inconsistency is that in most cases there is a huge distance between the strategic objectives of the corporation's operations and tactics plans ABU that R. H. Pridag and V. Schmidt was named as the methodological gap.

This gap arises from the fact that the basis of tactical plans and budgets of specific ABU are the already achieved results. Moreover, the strategic and tactical levels are separated among themselves and in the understanding of senior management of the corporation (Menz, 2012). This happens due to the following reasons:

- strategic factors reflect the possible ways to achieve pan- corporate goals, their changes, and the budget is that what has the specific $A B U$ at the moment;

- mission and arising from it strategic objectives often exist in oral form, and the budget has not only paper and electronic media, but also must pass the procedure of coordination and approval; 
- strategic plans operate mainly qualitative indicators, while the budget contains quantitative indicators.

The solution to this important for the corporation problem may be due to the use of indicative planning.

For this it is necessary to define control indicators, with the use of which in the current period the management of the corporation and $A B U$ can achieve the goals which has been set in the strategic indicative plan of the corporation.

In this aspect interesting is the balanced scorecard, developed in the late 1980's and early 1990's by D. Norton and R. Kaplan. These authors emphasize the "late indicators" and "early indicators".

\section{Materials and Methods}

Late indicators are closely associated with the data calculated at the end of the accounting period when summarizing. Typically, these include the data of the accounting statements and calculated on their basis coefficients.

Early indicators switch the attention of corporate management with the calculation of the profit and cash flows to analysis of the programs which at their realization in the current period will contribute to the achievement of planned in strategic indicative plan for the purposes of the corporation.

It was this vision allows to combine strategic indicative plan of the corporation and budgets of specific ABU. Within this approach it is necessary to develop adequate early indicators that, as the budget, will be based on the current position of the $\mathrm{ABU}$, which will allow them to be included in the budget at the development of early and late indicators under the strategic indicative of the corporate plan.

The scheme of a complex of works on the organization of the planning system in corporations and $A B U$ is transformed as following (see figures 1 and 2).

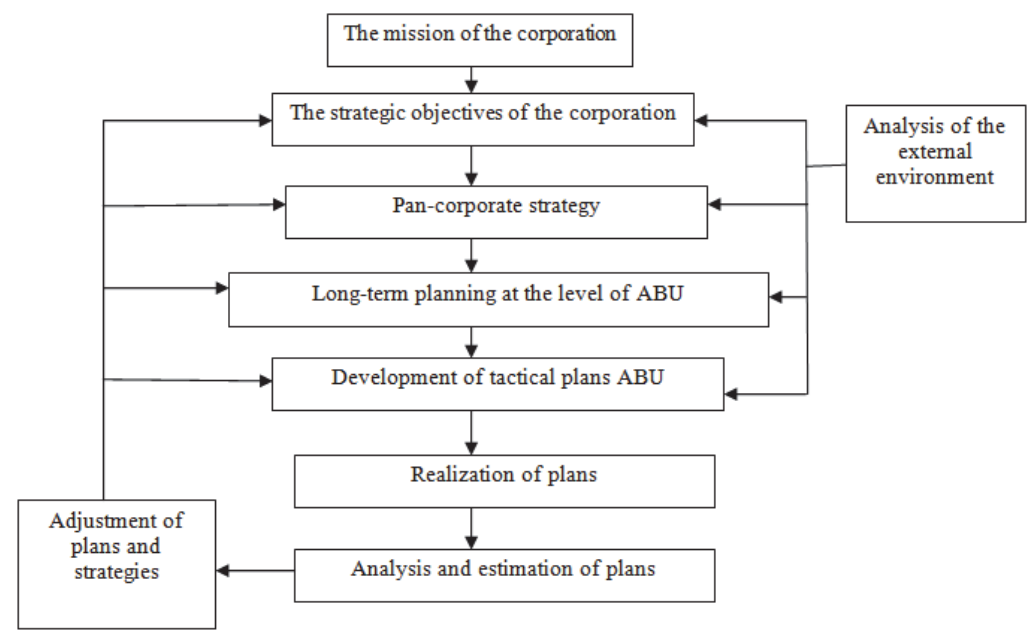

Figure 1. The integrated nature of planning at the corporate level

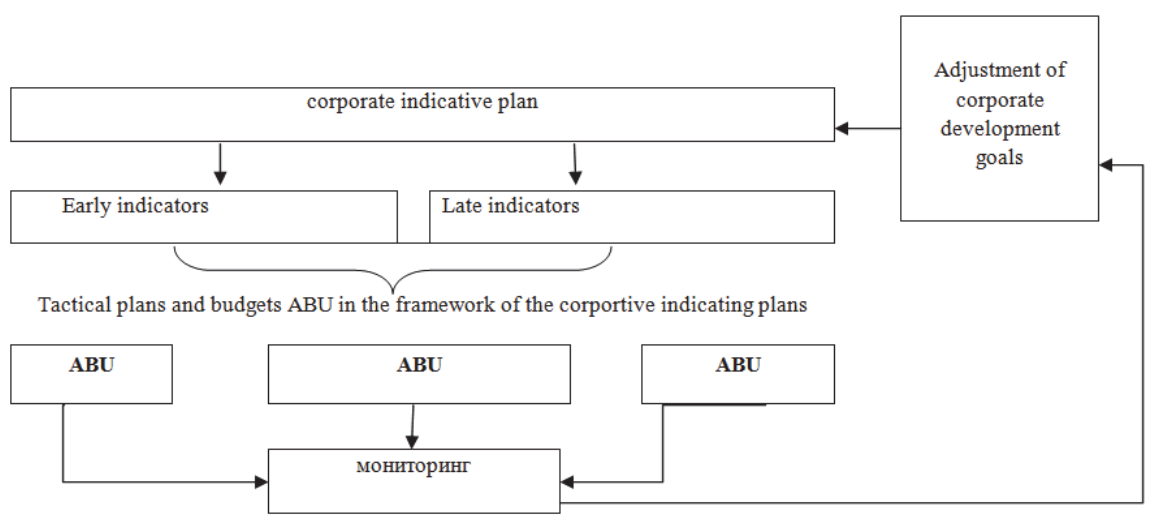

Figure2. The integrated nature of planning at the corporate level in the allocation of early and late indicators 
This approach requires the modification of the mechanism for making management decisions. At the corporate level it is necessary to select indicators in three sections:

- indicators, describing various aspects of operations (production, marketing, personnel, etc)

- indicators having different temporal periodization;

- early and late indicators.

A tool that allows to combine all three dimensions is called Precauski cube (see figure 3) Balanced scorecard: a guide to implementation (2006).

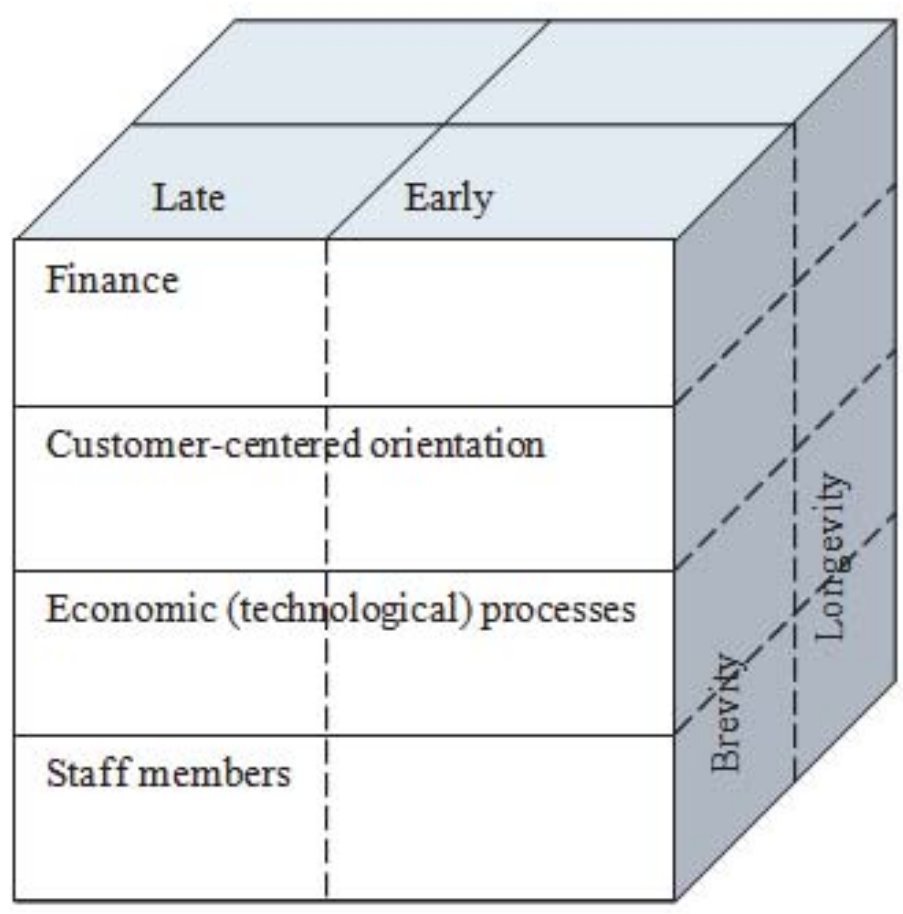

Figure 3. The three-dimensionality of the indicators in the balanced scorecard

Methodology of the separation of early and late indicators proposed by the German practitioners H. R. Pridag and V. Schmidt. The use of early and late indicators is widely spread in foreign practice. However for each individual enterprise the set of indicators is determined individually, on the basis of general recommendations.

In Russia, despite sufficient preparedness in the economic literature, this technique has not received wide practical application. In this connection it is expedient to consider the possibility of adapting it to Russian economic conditions with regard to corporate sector.

The selection of early and late indicators on the basis of forecasts and programs of the corporation, reflected in the indicative strategic plan. Any corporate structure, as well as its individual $A B U$, has an interest in effective interaction and satisfaction of customers, employees and owners. In integrated corporate structures in individual $A B U$ can be their own client base, determined by the specificity profile of the $A B U$, employees of $A B U$ are various, there can be a mismatch in varying degrees of owners for individual $A B U$ and in general for the corporation. In addition, within the corporate structure particularly important become issues of efficiency and a smooth internal business processes. This proves the necessity of development and application of indicators in such areas as:

- $\quad$ inancial (point of view of owners ABU as well as the corporation as a whole);

- personnel(training and development);

- client;

- business processes and engineering procedure.

The financial direction provides a set of indicators characterizing the effectiveness of the strategy of operation and development of the corporation as a whole and ABU.

Client direction characterizes the market segments in which the corporation and its ABU's plan to act and to 
participate in the competition. Indicators of this direction allows the ABU to comprehensively assess the level and dynamics of consumer demand, the ability and prospects of attracting new customers, methods of maintaining interest in the manufactured products, etc.

The direction of the business processes and engineering procedure characterize the optimality of on-farm processes of each $\mathrm{ABU}$ as well as internal corporate processes in general. culture.

Personnel direction describes the process of training and retraining of staff, creation of internal organizational

The first three areas (financial, customer, business processes and engineering procedure) contain a set of indicators contributing to effective operation of the corporate structure in general and individual ABU. Personnel direction contains indicators that help to achieve the objectives that were set out in other directions.

Additional direction of $\mathrm{ABU}$ are chosen independently according to the specific of activity.

AS the integrated corporation is a large company, interacting with many counterparties, in addition to the above key areas it is recommended to distinguish the following:

- communicative - characterizes the efficiency of internal and external communications (is associated with personnel direction and the direction of the business processes and technological engineering procedure);

- innovation - that direction characterizes the efficiency of the development, implementation and market introduction of innovations that in a timely conditions are a key factor of success (is most closely related to the direction of the business processes and engineering procedure, but potentially innovative direction to some extent is interconnected with all directions) ;

- the implementation of the system of assessment tools (indicators) - the direction which is characerised by efficiency of the development, implementation and use of a system of indicators (is linked to the areas of business processes and technological engineering procedure and personnel);

- organizational - characterizes the efficiency of the operation, including the flexibility and speed of reaction to changes of the organisational structure of corporate structure (is associated with personnel direction and the direction of the business processes and engineering procedure);

- advertising direction - characterizes the efficiency of advertising campaigns (is related to the direction of the business processes through indicators of external communications and with financial direction through the indicators of solvency);

- the direction of suppliers and contractors - characterizes the reliability of partnerships with suppliers and contractors of the corporation for corporate level and for individual $A B U$ - is related to the direction of the business processes and engineering procedure through indicators of secure and cost-efficientcy of suppliers and financial direction through the indicators of solvency);

- direction of credits - characterizes the reliability of partnerships with banks, credit organizations, lenders;

- direction of investors - characterizes the reliability of the relationship with investors, including the securities market, the attractiveness of the investment programs of the corporation;

- the direction of insurance companies - characterizes the reliability of partnerships with insurance companies.

The relationship of the basic directions of development of indicators is shown in table 1.

The granularity of individual directions is determined by the specific needs of $A B U$ and corporate structure in general. So, for example, under the personnel direction it is possible to outline directions of cooperation with organizations engaged in recruitment and training of staff. If for the corporation at any reasons, relevant become issues of efficiency of operations in the securities market, it is also possible to allocate a similar direction, characterizing the reliability of partnerships with investors in this market, also the attractiveness of securities of the corporation. However, the highliting of a large number of areas would be discouraged due to possible difficulties of operational control. Quantitative and meaningful part of the directions should be in close alignment with the corporate capabilities of an effective control and to determine the physical operation of the structure issues. Each of the directions contains a set of benchmarks and indicators, each of which refers to one of the groups: early long-term, early short-term late long-term, late short term. 
Table 1. The main directions of development of indicators and their relationship

\begin{tabular}{|c|c|c|c|}
\hline \multicolumn{2}{|l|}{ Direction } & \multirow{2}{*}{\multicolumn{2}{|c|}{ With which direction is connected }} \\
\hline Name & Characteristic & & \\
\hline \multicolumn{4}{|l|}{ Common directions } \\
\hline Financial & $\begin{array}{l}\text { lontains a set of indicators characterizing the effectiveness of the } \\
\text { strategy of operation and development of the corporation as a whole } \\
\text { and ABU. }\end{array}$ & \multicolumn{2}{|l|}{$\begin{array}{l}\text { Is associated with all directions, because namely } \\
\text { the financial plan determines ultimately the } \\
\text { feasibility and effectiveness of all management } \\
\text { decisions }\end{array}$} \\
\hline Client & $\begin{array}{l}\text { characterizes market segments in which the corporation and its } \\
\text { ABU's plan to act and to participate in the competition. Indicators of } \\
\text { the direction allows the ABU to comprehensively assess the level and } \\
\text { dynamics of consumer demand, the ability and prospects of attracting } \\
\text { new customers, methods of maintaining interest in the manufactured } \\
\text { products, etc.. }\end{array}$ & $\begin{array}{l}\text { is related to the direction of the business } \\
\text { processes and engineering procedure }\end{array}$ & \multirow{3}{*}{ 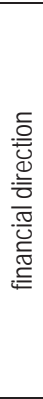 } \\
\hline Personnel & $\begin{array}{l}\text { Describes the process of training, retraining of staff, creation of } \\
\text { internal organizational culture, contains indicators to help achieve the } \\
\text { objectives set out in other directions. }\end{array}$ & $\begin{array}{l}\text { Is associated with the direction of the } \\
\text { business processes and engineering } \\
\text { procedure }\end{array}$ & \\
\hline $\begin{array}{l}\text { Business processes and } \\
\text { engineering procedure }\end{array}$ & $\begin{array}{l}\text { The direction of the business processes and engineering procedure } \\
\text { characterizes the optimality of intereconomic processes of each ABU } \\
\text { and internal corporate processes in general. }\end{array}$ & $\begin{array}{l}\text { associated with the personnel direction and } \\
\text { client direction }\end{array}$ & \\
\hline \multicolumn{4}{|c|}{ Additional (detalized) directions } \\
\hline Communicative & characterizes the efficiency of internal and external communications & $\begin{array}{l}\text { Is associated with the personnel direction and } \\
\text { the direction of the business processes and } \\
\text { engineering procedure }\end{array}$ & \\
\hline Innovative & $\begin{array}{l}\text { characterizes the efficiency of the development, implementation and } \\
\text { market introduction of innovations in a timely conditions are a key } \\
\text { factor of success }\end{array}$ & $\begin{array}{l}\text { Is most closely related to the direction of the } \\
\text { business processes and engineering } \\
\text { procedure, but is potentially innovative } \\
\text { direction to some extent interconnected with } \\
\text { all areas }\end{array}$ & \\
\hline $\begin{array}{l}\text { The implementation of } \\
\text { the system assessment } \\
\text { tools (indicators) } \\
\end{array}$ & $\begin{array}{l}\text { characterizes the efficiency of the development, implementation and } \\
\text { use of a system of indicators }\end{array}$ & $\begin{array}{l}\text { Is associated with the areas of business } \\
\text { processes and engineering procedure,and } \\
\text { personnel }\end{array}$ & \\
\hline Organizing & $\begin{array}{l}\text { characterizes the efficiency of the operation, including the flexibility } \\
\text { and speed of reaction to changes of the organisational structure of } \\
\text { corporate structure }\end{array}$ & $\begin{array}{l}\text { with the personnel direction and the direction } \\
\text { of the business processes and engineering } \\
\text { procedurec }\end{array}$ & \\
\hline Advertising direction & characterizes the effectiveness of advertising campaigns & $\begin{array}{l}\text { with the direction of the business processes } \\
\text { through indicators of external communications } \\
\text { and financial direction through the indicators } \\
\text { of solvency }\end{array}$ & \\
\hline $\begin{array}{l}\text { The direction of suppliers } \\
\text { and contractors }\end{array}$ & $\begin{array}{l}\text { characterizes the reliability of partnerships with suppliers or } \\
\text { contractors of the corporation at corporate level and for individual } \\
\text { ABU }\end{array}$ & $\begin{array}{l}\text { with the direction the business processes and } \\
\text { engineering procedure through indicators } \\
\text { secure and cost-efficient suppliers and } \\
\text { financial direction through the indicators of } \\
\text { solvency }\end{array}$ & \\
\hline Credits directions & $\begin{array}{l}\text { characterizes the reliability of partnerships with banks, credit } \\
\text { organizations, lenders }\end{array}$ & with the direction of the business processes & \\
\hline Interestes & $\begin{array}{l}\text { characterizes the reliability of the relationship with investors, } \\
\text { including the securities market, the attractiveness of the investment } \\
\text { programs of the corporation }\end{array}$ & $\begin{array}{l}\text { with the direction the business processes and } \\
\text { engineering procedure through indicators } \\
\text { secure and cost-efficient suppliers and } \\
\text { financial direction through the indicators of } \\
\text { solvency }\end{array}$ & \\
\hline Insurá & characterizes the reliability of partne & $\begin{array}{l}\text { with the direction the business processes and } \\
\text { engineering procedure }\end{array}$ & \\
\hline
\end{tabular}

Criteria for assigning a tool to a particular group is determined on the bases of works of $\mathrm{H}$. R. Fridag and V. Schmidt.

Let's consider the process of the reference of indicators to a particular group for example, the specific direction client. This area plays a key role in the functioning of the corporate structure, because it determines the market position of the company, level of service, awareness of the company and its products, and thus high financial results, earnings growth, financial solvency, market value, etc. In this area it is possible to select the following measurement areas: customer satisfaction and customer loyalty, attracting of new customers, customer profitability, market share, product quality and service, customer relations, image and reputation.

Adapting the methodology proposed by Kulik O.S. (2001), it is possible to propose the following classification of indicators of client direction (see table 2). 
Table 2. The classification of indicators of client direction

\begin{tabular}{|c|c|c|c|c|c|}
\hline \multirow{2}{*}{ The areas of analysis } & \multirow{2}{*}{ Indicator } & \multicolumn{4}{|c|}{ Characteristic } \\
\hline & & early & late & Long-term & Short-term \\
\hline \multirow[t]{4}{*}{ Satisfaction of clients } & the degree of customer satisfaction for existing products & & + & + & \\
\hline & the degree of customer satisfaction for new products & + & & + & \\
\hline & the number of surveys of customer satisfaction for existing products & & + & + & \\
\hline & the number of surveys of customer satisfaction for new products & + & & + & \\
\hline \multirow[t]{10}{*}{ Loyalty of clients } & the number of customers who switched to competitors & & + & & + \\
\hline & the costs associated with the loss of a client & & + & & + \\
\hline & The degree of customer's loyalty & & + & + & \\
\hline & the degree of loyalty of retail stores for products of the corporation (or ABU) & & + & + & \\
\hline & sales growth through existing customers & & + & + & \\
\hline & sales growth through new customers (repeat purchases) & & + & + & \\
\hline & sales growth of new products at the expense of existing customers & & + & + & \\
\hline & exports in existing areas and of existing products & & + & + & \\
\hline & export of existing products to new areas & & + & + & \\
\hline & exports of new products in existing areas & & + & + & \\
\hline \multirow[t]{10}{*}{ Attraction of new clients } & the costs of attracting a new customer & & + & & + \\
\hline & sales growth through new customers (first purchase/one time purchase) & & + & & + \\
\hline & the growth of sales of new products through new customers (one-time purchase) & + & & & + \\
\hline & the growth of sales of new products through new customers (retention as permanent) & + & & + & \\
\hline & export of existing products to new destinations (one-time purchase) & & + & & + \\
\hline & export of existing products to new destinations (repeat purchases) & & + & + & \\
\hline & export new products to new areas (repeat purchases) & & + & + & \\
\hline & export new products to new destinations (one-time purchase) & & + & & + \\
\hline & exports of new products in existing areas (one-time purchase) & & + & & + \\
\hline & exports of new products in existing areas (re-purchase) & & + & + & \\
\hline \multirow[t]{2}{*}{ Profitability of clients } & the profitability of the regions & & + & + & \\
\hline & the profitability of sales outlets & & + & + & \\
\hline \multirow[t]{6}{*}{ Market share } & market share in RF (or to another country, region, etc.) & & + & + & \\
\hline & market share of new products in RF (or another country) & + & & + & \\
\hline & the number of existing trade missions (in general or in the territorial context) & & + & + & \\
\hline & the number of new trade missions & + & & + & \\
\hline & Growth of sales & & + & + & \\
\hline & the change of volume of exports & & + & + & \\
\hline \multirow{7}{*}{$\begin{array}{l}\text { quality of products and } \\
\text { service }\end{array}$} & quality of product & + & & + & \\
\hline & percentage of clients satisfied with corporate interaction with customer & + & & + & \\
\hline & the loss of sales related to dissatisfaction with the service & + & & & + \\
\hline & the number of returns of products & + & & & + \\
\hline & product combination & + & & + & \\
\hline & the percentage of unique products (unparalleled) & + & & + & \\
\hline & the share of new products in total sales & + & & + & \\
\hline \multirow[t]{3}{*}{ Relations with clients } & the number of customer claims & + & & & + \\
\hline & the number of staff visits to key clients & + & & + & \\
\hline & the number of meetings with customers to clarify requests, ideas, claims analysis & + & & + & \\
\hline image and reputation & the magnitude of marketing costs & + & & + & \\
\hline
\end{tabular}

The important point is the separation of the indicators in the field of customer satisfaction on the associated with new products and existing products. In the case when it comes to new products there are early indicators. In terms of timing all indicators of this group should be classified as long-term as the permanent effects on the growth factors of satisfaction, requires constant monitoring of these indicators are in need.

Also as late should be included indicators related to the field of "customer loyalty". The assignment of this area to the group of late indicators is due to the fact that lack of attention to customers, ignoring their requests in the field of quality and service, etc. leads to the loss of customers, and, consequently, to financial losses. The indicators of the field "customer relations", "product quality and service", which relate to early, are important to minimize such losses. It should be noted that in the case where the corporation or its $A B U$, there is a need to assess the commitment of existing customers to purchase of new product, the region of indicators "loyal customers" can be seen as early indicators.

When deciding about the assignment of indicators of specific field to the category "short-term" or "long term", most of them should be attributed to long term, as they need constant monitoring, measuring, evaluating the influence of factors and taking appropriate action.

To the category of short term should be refered the number of customers who switched to competitors, and costs associated with the loss of a customer because of the need to take into account their presence and to prevent the 
recurrence of such situations.

Opportunities for business expansion are defined due to the presence of the corporation client. However, attracting of new customers is not a sufficient factor for success: one need to hold it, to gain its favor, encourage further purchases. In this direction it is advisable to apply early indicators from the field of "quality and service" in order to assess the effectiveness of the corporation or its ABU. The indicators of the field "attracting new customers" are early in the case that new products are analyzed.

Indicators "growth of sales of new products by new customers" and "export of new products to new destinations" should be long-term as they act for the long term. Other indicators of this region should be classified as short term.

Indicators of profitability, calculated on the basis of retrospective data already inherently are focused on the past, and, therefore, are late indicators. To obtain a desired coefficient of profitability, it is necessary to constantly monitor, adjust, take into account the influence of those or other factors affecting its value. Since the index is focused on the long term - these indicators relate to the long term.

As indicators of the "market share" characterize the achievement of the corporation or its ABU for any definite period of the past, they are late. All the indicators in this area are classified as long-term as long-term, as they are oriented to the long term outlook.

Early indicators include indicators of the "image and reputation" and "customer relationships" as indicators of these areas in conjunction with the indicators "product quality and service" allow to evaluate customer satisfaction with products, the effectiveness of efforts to retain existing and attract new customers, expand market share. These indicators are essential - that is where corporate management should have an impact in the first place.

Following from the test directions - staff - is of particular interest because it influences all other areas: customer, financial, business processes and engineering procedure.

Namely personnel potential determines the possibility of building an optimal business processes, setting up internal and external communication systems, which in it's turn affects the success factors of the client and financial trends, affect all an additionally distinguished directions.

Indicators of personnel direction can be divided into seven areas (see table 3).

Among the indicators "the degree of satisfaction of employees"- only one - "readiness for unpaid overtime" - is focused on the short term: corporate management should take measures to address such situations.

Other indicators of this area are focused on the long term outlook, require constant attention and monitoring, and should therefore be classified as long term.

Table 3. The classification of indicators of personnel direction

\begin{tabular}{|c|c|c|c|c|c|}
\hline \multirow[t]{2}{*}{ Area of analysis } & \multirow[b]{2}{*}{ Indicator } & \multicolumn{4}{|c|}{ Characteristic of indicator } \\
\hline & & early & late & $\begin{array}{l}\text { Long- } \\
\text { term }\end{array}$ & $\begin{array}{l}\text { Short- } \\
\text { term }\end{array}$ \\
\hline \multirow{4}{*}{$\begin{array}{l}\text { The level of } \\
\text { satisfaction of } \\
\text { clients }\end{array}$} & employee satisfaction & & + & + & \\
\hline & the percentage of sickness days & & + & + & \\
\hline & readiness for unpaid overtime & & + & & + \\
\hline & recognition of achievements (awards) & & + & + & \\
\hline \multirow{4}{*}{\begin{tabular}{|l|} 
Loyalty of \\
employees
\end{tabular}} & the average operation time in the corporation, years & & + & + & \\
\hline & layoffs among employees who were hired within the last 5 years & & + & + & \\
\hline & the turnover rates for key personnel & & + & + & \\
\hline & percentage of employees who hold shares in the corporation & & + & + & \\
\hline \multirow{3}{*}{$\begin{array}{l}\text { Employees } \\
\text { productivity }\end{array}$} & turnover per employee & & + & + & \\
\hline & labour productivity & & + & + & \\
\hline & the profitability of the staff & & + & + & \\
\hline \multirow{3}{*}{$\begin{array}{l}\text { Further training of } \\
\text { employees }\end{array}$} & learning cost & + & & + & \\
\hline & the amount of ideas and proposals to optimize business and engineering procedure, perceived training & + & & + & \\
\hline & the number of proposals on optimization for 1 employee, who has been trained & + & & + & \\
\hline \multirow{6}{*}{$\begin{array}{l}\text { Motivation of } \\
\text { employees }\end{array}$} & index of motivation & + & & + & \\
\hline & the number of proposals to streamline business processes and engineering procedure per employee & + & & + & \\
\hline & the total number of proposals for streamlining business processes and engineering procedure & + & & + & \\
\hline & $\begin{array}{l}\text { the total number of proposals for streamlining business processes and engineering procedure from } \\
\text { groups of employees }\end{array}$ & + & & + & \\
\hline & ability to work in a team & + & & + & \\
\hline & percentage of employees, organizing work strategically & + & & & + \\
\hline \multirow{2}{*}{\begin{tabular}{|l|l|l} 
Information \\
infrastructure
\end{tabular}} & the time to use information systems by managers & + & & + & \\
\hline & number of improvement corporate computer programs & + & & + & \\
\hline \multirow{2}{*}{$\begin{array}{l}\text { The professionalism } \\
\text { of the staff }\end{array}$} & the number of staff errors & + & & & + \\
\hline & deviation from standards and budgets & + & & & + \\
\hline
\end{tabular}


All indicators in the field of "loyalty to employees" are long-term oriented, in relation to them constant monitoring is required and, consequently, the area should be classified as long-term indicators.

The indicators area "employee productivity" refers to late, as evidenced by the nature of them: they all require obtaining of primary data - data on the number of employees, volume of production, sale, turnover, etc. The indicators in this area are focused on the long term outlook, require analysis and consideration of factors affecting their level, and should be classified as long term.

The indicators area "further training of employees" is of paramount importance because their positive dynamics demonstrated an increased employee satisfaction, maximize their productivity This area is closely linked to the area "loyalty to employees": the positive values of the indicators in this area has a positive effect on the loyalty of employees (Seema Mehta et al 2010; Ryazantsev et al 2015; Anne Martensen, Lars Grønholdt, 2006 ).

Important meaning of indicators of this area is to refer them to early. At the same time these indicators are longterm, since it is necessary to constantly monitor the cost of training and the effect as the sum of ideas and proposals received during training events.

In part of the area of employee motivation it should be noted that the use of indicators characterizing the targeted development of presented by staff rationalization proposals is a necessary, not sufficient condition of analysis of employee satisfaction. Without the appropriate motivation the use of staff will not be sufficiently effective. To eliminate this disadvantage it is advisable to introduce such an early indicator as an "index of motivation". This indicator has a longterm nature, because it requires an assessment of motivation, identification and analysis of factors affecting it (Karabulatova \& Polivara, 2015 \& Khairullina \& Karabulatova, 2014).

Indicators, characterizing the system of rationalization of proposals should be early, focused on the long term outlook: motivation of employees to achieve the goals as an individual $A B U$ and corporate structure as a whole, through active participation, implementation of rationalization ideas, which will be considered and paid by management, are implemented in the system of corporate governance, this will have a positive impact on job satisfaction of employees, will help the corporation to be successful, to meet the needs of clients and, ultimately, to achieve strategic goals. These goals may be different, but they are subject to corporate and / or the social order (Ryazantsev et al, 2014; Karabulatova et al, 2015).

The necessity of selection of the indicator characterizing the share of employees, organizing work strategically, is due to the fact that managers should implement the developed strategies of the corporation. Moreover, the use of this indicator will allow to avoid a situation where the management of the corporation, forgets about maximizing profit in the long term in the pursuit of high bonuses. This indicator is focused on the short term because it requires a one-time effort to determine the scope of responsibility and authorities.

For effective strategic and current activities of the corporation indicators of the information structure are extremely important. These indicators determine the effectiveness of systems of internal and external communication, efficiency system partnerships with contractors. This type of indicators should be refered to early.

All the indicators in this area are focused on the long term outlook.

Under personnel direction it is also possible to allocation such areas of indicators as professionalism of the staff. As professionalism in most cases, is a determinant of satisfaction and loyalty of employees, indicators of the group should be attributed to early. These indicators are focused on the short term outlook because they require an immediate response to the facts of human error and significant deviations from the regulations.

The direction indicators of the business processes can be divided into several areas depending on which aspect of the process is selected as the object for analysis (see table 4).

Table 4. Classification of direction indicators of business processes and manufacturing processes

\begin{tabular}{|c|c|c|c|c|c|}
\hline \multirow[b]{2}{*}{ Areas of analysis } & \multirow[b]{2}{*}{ Indicator } & \multicolumn{4}{|c|}{ Characteristic of indicator } \\
\hline & & early & late & $\begin{array}{l}\text { Long- } \\
\text { term }\end{array}$ & $\begin{array}{c}\text { Short- } \\
\text { term }\end{array}$ \\
\hline \multirow[t]{10}{*}{ The optimal business processes } & фондоотдача & & + & + & \\
\hline & the effectiveness of advertising and PR - companies & & + & + & \\
\hline & loss of the spoilage & + & & & + \\
\hline & cases of environmental pollution & + & & & + \\
\hline & $\begin{array}{l}\text { the cases of deviation of the quality of raw materials and finished products } \\
\text { from corporate standards }\end{array}$ & + & & & + \\
\hline & the response time to complaints & + & & & + \\
\hline & $\begin{array}{l}\text { accurate and high-quality execution of orders for the supply of raw materials } \\
\text { by suppliers }\end{array}$ & + & & + & \\
\hline & the number of customers ideas, implemented in the production & + & & + & \\
\hline & the breeding of new products to the market & + & & + & \\
\hline & compliance with international standards & + & & + & \\
\hline
\end{tabular}




\begin{tabular}{|c|c|c|c|c|c|}
\hline \multirow[b]{2}{*}{ Areas of analysis } & \multirow[b]{2}{*}{ Indicator } & \multicolumn{4}{|c|}{ Characteristic of indicator } \\
\hline & & early & late & $\begin{array}{l}\text { Long- } \\
\text { term }\end{array}$ & $\begin{array}{l}\text { Short- } \\
\text { term }\end{array}$ \\
\hline \multirow{4}{*}{$\begin{array}{l}\text { The efficiency of internal } \\
\text { communication }\end{array}$} & the amount included in the reporting of indicators & + & & & + \\
\hline & the number of summary budget forms & + & & & + \\
\hline & the number of hierarchical levels to 100 employees & + & & & + \\
\hline & $\begin{array}{l}\text { the degree of distribution of corporate press, the number of staff, involved in } \\
\text { the creation of corporate publications }\end{array}$ & + & & + & \\
\hline \multirow{2}{*}{$\begin{array}{l}\text { The effectiveness of external } \\
\text { communications }\end{array}$} & external distribution of the corporate publication & + & & + & \\
\hline & the number of notes about corporation in media & + & & + & \\
\hline \multirow{3}{*}{$\begin{array}{l}\text { The effectiveness of changes B } \\
\text { organizational structure (as in the } \\
\text { whole of the corporation and } \\
\text { within the individual } A B U \text { ) }\end{array}$} & the number of distinguished $A B U$ & + & & & + \\
\hline & the number of allocated responsibility centers & + & & & + \\
\hline & the number of allocated profit centers & + & & & + \\
\hline \multirow{2}{*}{$\begin{array}{l}\text { The effectiveness of the design } \\
\text { and implementation of the system } \\
\text { of indicative planning in the } \\
\text { framework of the corporate } \\
\text { structure, and ABU }\end{array}$} & the number of selected indicators at the level of $A B U$ & + & & & + \\
\hline & the number of selected indicators at the corporate level & + & & & + \\
\hline
\end{tabular}

Such indicators of the area of optimality of business processes, such as capital productivity, performance advertising (PR) companies should be attributed to late long-term, since by their nature they are focused on retrospective.

Such indicators of the area of optimality of the business processes as loss of spoilage, pollution, inconsistencies of raw materials and finished products to quality requirements and the time of response to the complaint should be treated as early, as they characterize the factors of success of the corporation in the context of business processes. Without building of optimal, effective business processes cannot be achieved the objectives of the client and financial trends. Non-fine-tuned business processes has a negative impact on all directions.

Other indicators of this area should be regarded as early long-term indicators. Also early are indicators of efficiency of internal communication. With the help of internal communication employees of the corporation are informed about its mission, vision and strategy. Through communications the corporation achieves the objectives defined in client and financial direction, to increase the profitability and efficiency of operation. All indicators in this group require an immediate response to deviations and therefore belong to the early. The exception is the indicator that characterizes the degree of prevalence of intra-corporate press, requiring constant exposure and control, and which is of long-termed outlook. The indicators of effectiveness of changes in organizational structure and implementation of the system of indicative planning, are primarily aimed to optimize business processes, to develop and organize strategic objectives. Therefore they refer to early. It should be noted that within these areas, the analysis must be lead both in terms of corporate structure as a whole and for individual $\mathrm{ABU}$, which will allow to estimate the degree of integration of individual $A B U$ in the corporate structure and the appropriateness of the inclusion/exclusion of this ABU's from the corporation.

All of these indicators should be classified as short term because they require measures to avoid negative situations in the future or measures in a single implementation and further effective use of related processes in corporate practice.

\section{Conclusion}

The financial direction is the most important for the corporation. Indicators of this trend reflect the achieved results. Thus, they are late, as are focused on the past. In this area it is possible to highlight an early indicator - solvency margin. At the condition of this indicator an operational decisions about payments from the account are made, daily payments and liquidity in crisis situations are monitored.

In the proposed system of indicators, if necessary, can be included additional directions that characterize the relationship of the corporation with financial system, suppliers, service providers, advertising companies, etc.

The use of early and late indicators provides the link between corporate indicative plan and operational, investment, financial and consolidated budgets of the ABU.

The effectiveness of the application of system of indicators within the corporate structure can be evaluated as following: if, at exposing at early indicators late indicators change in planned way, the use of this system within the corporation is effective. 


\section{References}

Balanced scorecard: a guide to implementation (2006). Edited by Herwig R. Fridag, V. Schmidt. M.: Omega-L. pp. 267.

Kulik, O.S. (2001) Application of indicators of the balanced scorecard in the improvement of the methodology of financial planning of the enterprise activity. In the: Finance and credit, No. 25, pp. 408.

Menz, M. (2012). Functional Top Management Team Members: A Review, Synthesis, and Research Agenda. Journal of Management, 38(1). pp. 45-80.

Seema, Mehta,Tarika Singh, Bhakar S.S. \& Brajesh Sinha (2010). Employee Loyalty towards Organization A study of Academician, electronic resource.

Ryazantsev, S.V., Karabulatova I.S., Manchin R.V., Pismennaya E.E. \& Sivoplyasova S.Y. (2015) Actual Problems of Human Trafficking and Illegal Migration in the Russian Federation In the: Mediterranean Journal of Social Science. Vol 6, No3, Supplement 1. pp. 610-615.

Ryazantsev, S.V., Pismennaya E.E., Karabulatova I.S. \& Charif Y. Akramov (2014) Transformation of sexual and matrimonial behavior of Tajik labor migrants in Russia. In the: Asian Social Science. Vol 10, No.20, 2014.

Anne, Martensen, Lars Grønholdt (2006). Internal marketing: a study of employee loyalty, its determinants and consequences, Electronic resource, http://businessperspectives.org/journals_free/im/2006/im_en_2006_04_Martensen.pdf.

Karabulatova, I.S., Polivara Z.V. Intraethnic installation of Ukrainian Labour migtants in the preservation of linguistic and cultural identity. In the: Mediterranean Journal of Social Science. 2015. Vol 6, No3, S2, May 2015. - pp.: 142-148.

Karabulatova, I.S., Khachmafova Z. R., Bricheva M. M., Nescheretova T.T. \& Asya K. Bersirova (2015). Linguopragmatic Aspect of "Search for the Ideal" in the Discourse of Female Fiction as a Reflection of Matrimonial-Demographic and Sexual Behavior in Contemporary Russian Society. Review of European Studies. Vol. 7. No 6. pp. 35-45.

Khairullina, N.G. \& Karabulatova I.S. (2014) Bailiff's Social Portrait. In the: Middle-East Journal of Scientific Research 19 (3). pp. $417-$ 420. 